\title{
Index for Volume 25 of Molecular Plant-Microbe Interactions
}

\author{
AUTHOR AND SUBJECT INDEX
}

AAL toxin, programmed cell death in Nicotiana umbratica and, ethylene signaling, MAPK cascades and, 1015

Abd El Rahman, T., 1584

Abramowski, D., 1469

ACC deaminase, effects of on gene expression in Brassica napus, 668

Achor, D. S., 1396

Acosta-Jurado, S., 825

Acquired resistance, in barley by Pseudomonas pathosystem, similarity to Arabidopsis systemic acquired resistance, 658

ACRST2 gene, Alternaria alternata on rough lemon and, 1419

Actin, immunodominant membrane protein of Candidatus Phytoplasma mali and, 889

$N$-Acyl-homoserine lactones (AHL), GCR1 and GPA1 and Arabidopsis primary root elongation, 677

Adams, D. G., 1338

Aeschynomene evenia, as model plant for studying nod-independent rhizobium-legume symbiosis, 851

Affourtit, J. P., 1350

AGP. See Arabinogalactan proteins

Agrobacterium spp., horizontal gene transfer to

Linaria vulgaris in nature, 1542

Agüero, J., 1326

AHL. See $N$-acyl-homoserine lactones (AHL)

Ait Barka, E., 241, 496

Akimitsu, K., 1419

Akimoto-Tomiyama, C., 505

Akita, M., 363

Alfalfa. See Medicago sativa

Alfalfa mosaic virus (AMV), coat protein of, roles of $\mathrm{N}$-terminal basic motif of, 1093

Alkan, N., 85

Allen, S. M., 765

Almeida, R. P. P., 453

Alternaria spp.

A. alternata, on rough lemon, ACRST2 gene and biosynthesis of ACR toxin, 1419

A. brassicicola on Arabidopsis thaliana, metabolite profiling of effect of ascorbate on, 1628 Vf19 gene and virulence of, 443, cover photo: April

A. solani, on tomato, salicylic acid and disease development, 1584

Ammonium secretion, Colletotrichum coccodes on tomato and, salicylic and jasmonic acid pathway induction and, 85

Ando, S., 1171

Anstead, J. A., 839

Antibodies, against Fusarium virguliforme, soybean disease resistance and, 817 , cover photo: June

Aparicio, F., 1093

Aphis gossypii, on melon, miRNA expression profile during aphid herbivory in resistant and susceptible interaction, 839

Aquaporins, of desert truffle, as membrane pore for water and carbon dioxide transport, 259

Arabidopsis thaliana

Activation of MPK11 by flg22 in, 471

Alternaria brassicicola on, metabolite profiling of effect of ascorbate on, 1628
Erwinia amylovora on, EDS1 and nonhost resistance, 421

as model host for Xylella fastidiosa, 747

Arabinogalactan proteins (AGP)

in Nostoc spp. and in plant-Nostoc symbioses, 1338

from Rhizobium leguminosarum bv. viciae, novel type of polar surface attachment and, 250

Aranda, M. A., 107

Arasimowicz-Jelonek, M., 1469

Ardiles-Diaz, W., 637

Aromatic compounds

Cochliobolus heterostrophus on maize and, 931

Colletotrichum fragariae on strawberry, host defense response and, 1430

Fusarium graminearum on maize and, 1605

Arrighi, J.-F., 851

Ascorbate, Alternaria brassicicola on

Arabidopsis thaliana and, 1628

Asurmendi, S., 1370

Atanasova-Penichon, V., 1605

Athinuwat, D., 1132

Atsumi, G., 1219

Auger, B., 993

Avr proteins

functional differentiation in the leucine-rich repeat domains of closely related plant virus-resistance proteins recognizing, 1219 Xanthomonas spp. on pepper and, 307

AvrLm1 gene, from Leptosphaeria maculans, salicylic acid and ethylene signaling in Brassica napus and, 1238

Awr gene family, of Ralstonia solanacearum encoding novel class of type III effectors displaying virulence and avirulence activities, 941

Azoarcus sp. strain $\mathrm{BH} 72$, interactions with rice, flagella and endophytic competence, 191

Baechler, N., 1198

Bai, P., 755

Bai, Y., 372

Baillieul, F., 241

Baker, C. J., 582

Baldan, B., 1387

Baltrus, D. A., 877

Banfield, M. J., 1118

Barad, S., 779

Baraldi, E., 1118

Barash, I., 231

Barley. See Hordeum vulgare

Barny, M.-A., 421

Barreau, C., 1605

Baum, T., 1314

Baurès, I., 341

Bean, Pseudomonas syringae on, molecular basis of host specialization in pathovars of, 877

Becker, J. D., 976

Beet necrotic yellow vein virus (BNYVV), P25 pathogenicity factor of, sugar beet $26 \mathrm{~S}$ proteasome and hypersensitive resistance response, 1058

Begomovirus spp., causing tomato yellow leaf curl disease, functional analysis of gene-
Page numbers in bold indicate errata.

silencing suppressors from, 1294, cover photo: October

Behr, M., 1073

Bejarano, E. R., 1294

Bendahmane, A., 341

Bentley, J. S., 1026

Bernoux, M., 379

Beta vulgaris (sugar beet), 26S proteasome and hypersensitive resistance response, $\mathrm{P} 25$ pathogenicity factor of Beet necrotic yellow vein virus and, 1058

Bethke, G., 1628, 471

Bharti, A. K., 1350

Bhattacharjee, S., 862

Bhattacharyya, M. K., 817

Bian, Z., 677

Biddle, E. M., 37

Biggs, M. B., 1026

Bijsterbosch, G., 910

Billert, H., 1469

Bisseling, T., 954

Bistable gene expression, in type III secretion system of Dickeya dadantii, 37

Biswas, S., 877

Bitton, F., 421

Björkman, T., 1264

Blumeria graminis f. sp. hordei, on barley, genes regulating Mla-triggered immunity and basal defense, 1492, cover photo: November

BMV. See Brome mosaic virus

BNYVV. See Beet necrotic yellow vein virus

Bodrossy, L., 28

Bogomaz, D. I., 1542

Bóka, K., 1238

Bombarely, A., 1523

Bond, C. S., 515

Bonnin-Verdal, M.-N., 1605

Boonrod, K., 889

Bordiec, S., 241, 496

Bormann, J., 1142

Botanga, C. J., 1628

Botrytis cinerea

Sak1 of, regulatory functions of, 802

type 2a phosphoprotein phosphatase and an SPT3 transcription factor and virulence of, 481

Bouarab, K., 1584

Bouchereau, A., 1478

Boursot, M., 851

Boyd, L. A., 658

Boyle, P., 1459

Bradeen, J. M., 603

Bradyrhizobium spp

B. japonicum, on soybean, ECF16 sigma factor EcfS and, 119, cover photo: January

MLST method for genotype identification and establishing soybean nodule occupancy, 321

Brar, D., 28

Brar, H. K., 817

Brassica napus (canola; oilseed rape)

AvrLm1 gene from Leptosphaeria maculans and, salicylic acid and ethylene signaling, 1238

effects of bacterial ACC deaminase on gene expression in, 668 
germination stimulants of Phelipanche ramosa in rhizosphere of, 993

Plasmodiophora brassicae on, metabotyping for investigating metabolic response to, 1478

Verticillium longisporum on, expression of catalase peroxidase and late stage of disease, 569

Braus, G. H., 569

Braus-Stromeyer, S. A., 569

Brígido, C., 1594

Brlansky, R. H., 1396

Brome mosaic virus (BMV), mutations in antiviral RNA defense pathway, RNA recombinant profile modification and, 97

Brooks, F., 443

Brown, S. C., 851

Buendía-Clavería, A. M., 825

Bujarski, J. J., 97

Burbank, L., 463

Burketová, L., 1238

Burkholderia phytofirmans, grape and

modulation of carbohydrate metabolism and cold acclimation, 496

tolerance to low nonfreezing temperatures and, 241

Burr, T. J., 1132

Buschart, A., 191

Butrón, A., 61

Cabral, A., 697

Calla, B., 6

Camañes, G., 709

Candidatus spp.

$\mathrm{Ca}$. Liberibacter asiaticus, comparative transcriptional and anatomical analyses of tolerant rough lemon and susceptible sweet orange, 1396

Ca. Phytoplasma mali, immunodominant membrane protein of, binding to plant actin, 889

Candresse, T., 341

Cañizares, J., 107

Cano, L. M., 910, 1350

Canola. See Brassica napus

Capsicum spp. (pepper)

$L$ genes of and evolution, 1219

Tobacco etch virus in, determination of infectivity by three amino acids in $\mathrm{VPg}$, 1562

Xanthomonas spp. on, AvrBs proteins and hypersensitive response, 307

Carbohydrate metabolism, Burkholderia phytofirmans and, grape cold acclimation and, 496

Carbonell, A., 151

Carolo, P., 1605

Cartieaux, F., 851

Carvalho, H. G., 976

Castagnaro, A. P., 1430

Catalase peroxidase, Verticillium longisporum on oilseed rape and, 569

CCHD1 gene, Cochliobolus heterostrophus on maize and, 931

CD38, systemic acquired resistance in

Arabidopsis thaliana and, 1209

Cell wall-degrading enzymes (CDWE)

Alternaria brassicicola virulence and, 443 , cover photo: April

Pantoea stewartii subsp. stewartii virulence on corn and, 463

Cellulases, Magnaporthe oryzae virulence and, 1135

Cermola, M., 331

Chaintreuil, C., 851

Chalupowicz, L., 231

ChAP1, Cochliobolus heterostrophus on maize and, 931
Charton, S., 1478

Chatnaparat, T., 1104

Chatterjee, S., 453, 789, 1157

Chen, C., 1396

Chen, C.-E., 738

Chen, H., 1361

Chen, H.-H., 738

Chen, J.-G., 765

Chen, M.-S., 920

Chen, X., 191

Chen, Z., 1628

Cheng, B., 1639

Cheng, Y. T., 1459

Chertkov, O., 1350

Chickpea. See Cicer arietinum

Chitin, induction of immunity and ethyleneresponsive element-binding factor 5 (ERF5), 48

Chiurazzi, M., 211

Chiusano, M. L., 603

Chlorogenic acid, Fusarium graminearum on maize and, 1617

Cho, Y., 443

Choi, D., 534

Choi, G. J., 1617

Choi, J., 534

Chung, W. S., 48

Cicer arietinum (chickpea), clpB gene of Mesorhizobium ciceri and root nodulation, 1594

Citrus leaf blotch virus (CLBV), development of viral vector based on, 1326

Citrus spp.

C. jambhiri (rough lemon), Alternaria alternata on, ACRST2 gene and biosynthesis of ACR toxin, 1419

Xanthomonas citri subsp. citri on, highthroughput screening and analysis of genes involved in virulence, 69

Clark, C. A., 393

Clarke, N., 1450

CLBV. See Citrus leaf blotch virus

Clément, C., 241, 496

Clement, M. J., 1026

Clement, S. C., 1026

Clough, S. J., 6

$C l p B$ gene, of Mesorhizobium ciceri, nodulation of chickpea and, 1594

CMV. See Cucumber mosaic virus

Coat protein $(\mathrm{CP})$

of Alfalfa mosaic virus, roles of N-terminal basic motif of, 1093

of Hibiscus chlorotic ringspot virus, upregulation of sulfur metabolism genes for enhanced pathogen defense and, 1574

of Tobacco mosaic virus, plant basal defense and biotic stress responses in Nicotiana tabacum and, 1361

Cochliobolus heterostrophus, on maize, use of aromatic compounds as signals and metabolites, 931

Cock, P. J. A., 6

Coker, F., 1034

Colebrook, E. H., 658

Collado, I. G., 802

Colletotrichum spp.

C. coccodes, on tomato, ammonium secretion during infection and salicylic and jasmonic acid pathways, 85

C. fragariae, on strawberry, ellagitannin accumulation and plant defense response, 1430

C. gloeosporioides, nitrogen-metabolism genes expressed during pathogenicity of, differential expression in acidifying pathogens, 1251

C. graminicola, on maize, remodeling cytokinin metabolism at infection sites, 1073
C. orbiculare

$L A C 2$ and appresorial melanization and conidial pigmentation in, 1552

on Nicotiana benthamiana, induction and suppression of cell death by secreted proteins of, 625

Conti, G., 1370

Corn, see Zea mays

Corn borer. See Sesamia nonagrioides

Cornelissen, B. J. C., 1045

Coronatine, Pseudomonas syringae pv. tomato on tomato and, 294

Creissen, G., 658

Crespo-Rivas, J. C., 825

Crook, M. B., 1026

Cuartas-Lanza, R., 523

Cubo, M. T., 825

Cucumber mosaic virus (CMV)

in Nicotiana benthamiana, synergism with Turnip mosaic virus, 18

in tomato, D satellite RNA, lethal systemic necrosis and, 1034

yellow strain (CMV[Y]), $R C Y 1$-mediated resistance to, 1171

Cucumber vein yellowing virus (CVYV), $\mathrm{P} 1 \mathrm{~b}$ silencing suppressor of, functional replacement of Plum pox virus HCPro and, 151, cover photo: February

Cucumis melo (melon)

Aphis gossypii on, miRNA expression profile during aphid herbivory in resistant and susceptible interaction, 839

Watermelon mosaic virus in, recessive resistance associated with induction of defense response genes in, 107

Cursino, L., 1132

CVYV. See Cucumber vein yellowing virus

CWDE. See Cell wall-degrading enzymes

Cytokinins, Colletotrichum graminicola on maize and, remodeling metabolism at infection sites, 1073

D satellite RNA, lethal systemic necrosis in tomato and, 1034

Dai, T., 896

Dalla Serra, M., 1118

Dandelion. See Taraxacum officinale

Dangl, J. L., 877

De Backer, P., 637

de Castro, P. A., 613

De Keyser, A., 637

De La Fuente, L., 1132

de Lacoba, M. G., 709

De Rycke, R., 637

Deckert, J., 1469

Defensin-like (DEFL) genes, characterization of in grapevine, 1104

Degrave, A., 421

Deising, H. B., 1073

del Carmen Vives, M., 1326

Delaruelle, C., 279

Delavault, P., 402, 993

Delourme, R., 993, 1478

Deoxynivalenol, Fusarium graminearum on maize and, 1605

Desert truffle. See Terfezia claveryi

Deslandes, L., 941

Després, C., 1459

Detter, C., 1350

Dhondt-Cordelier, S., 241

Díaz Ricci, J. C., 1430

Diaz-Minguez, J. M., 1251

Díaz-Ruíz, J. R., 709

Dickeya dadantii

genome-wide analysis of response to plant antimicrobial peptides, 523

strain 3937 , bistable gene expression of type III secretion system in, 37 
Dictyochloropsis reticulata, Lobaria pulmonaria and, congruent genetic structure in, 220

Diener, A., 1531

Diez-Roux, G., 331

Diffusible signaling factor (DSF)

Xanthomonas citri subsp. citri gene expression and, 165

in Xanthomonas oryzae pv. oryzae, atypical regulation of virulence-associated functions by, 789

Xylella fastidiosa cell-to-cell signal synthesis, virulence, and vector transmission of, 453

Dinwiddie, D. L., 1350

Dirks, M. E., 200

DN3, Colletotrichum orbiculare on Nicotiana benthamiana, suppression of cell death and, 625

Dodds, P. N., 379

Doktycz, M. J., 765

Donahoo, R. S., 1350

Dong, S., 1639, 896

Dong, Y., 431, 1408

Döring, J., 28

Double stranded RNA (dsRNA), in arbuscular mycorrhizal fungi, 1005

Dougherty, K. M., 877

Downie, J. A., 250

Dreos, R., 658

Drought, Trichoderma harzianum on tomato and defense against, 1264

Druebert, C., 569

DSF. See Diffusible signaling factor

Dubrana-Ourabah, M.-P., 341

Ducos, C., 1605

Dudler, R., 1198

Dujovny, G., 151

Duplessis, S., 279

Dzianott, A., 97

Eardly, B. D., 321

EcfS gene, of Bradyrhizobium japonicum, symbiosis with soybean and, 119, cover photo: January

EDS1, nonhost resistance against Erwinia amylovora in Arabidopsis thaliana and, 421

Edwards, A., 250

Effector-triggered immunity (ETI) gene-to-gene pathways to protein-protein interaction networks, 862

against Melampsora larici-populina on poplars, 279

ToxA genes from Stagonospora nodorum and Pyrenophora tritici-repentis and, 515

Elia, P., 321

Ellagitannin, Colletotrichum fragariae on strawberry, host defense response and, 1430

Ellis, J. G., 379

eNAD $(\mathrm{P})$, systemic acquired resistance in Arabidopsis thaliana and, 1209

Endoglucanase, Pantoea stewartii subsp. stewartii virulence on corn and, 463

Endophytes

colonizing rice roots, metagenomic analysis of, 28

Piriformospora indica, molecular and genomic analysis of lifestyle, 727

rice-Azoarcus sp. strain $\mathrm{BH} 72$ interactions, flagella and endophytic competence, 191

ERF5. See Ethylene-responsive element-binding factor 5

Erwinia amylovora

on Arabidopsis thaliana, EDS1 and nonhost resistance, 421

genome-wide identification of genes regulated by Rcs phosphorelay system in, 6

Eschen-Lippold, L., 471
Espino, J., 481

Espino, J. J., 802

Espuny, M. R., 211

Ethylene

programmed cell death in Nicotiana umbratica and, AAL toxin, MAPK cascades and, 1015

signaling in Brassica napus, AvrLm1 gene from Leptosphaeria maculans and, 1238

Ethylene-responsive element-binding factor 5 (ERF5), chitin-induced innate immunity response and, 48

Extreme resistance, of soybean against Soybean mosaic virus, multiple defense genes in Rsv1mediated, 1307

Ezawa, T., 1005

Fabre, S., 851

Fagard, M., 421

Fan, J., 1396

Fardoux, J., 851

Faris, J. D., 515

Faure, C., 341

F-box family proteins (FBK), P25 pathogenicity factor of Beet necrotic yellow vein virus and $26 \mathrm{~S}$ proteasome of sugar beet and, 1058

Feau, N., 279

Fedorova, E., 954

Feil, R., 496

Feng, H., 755

Ferguson-Hunt, M., 515

Fernandez, J., 1286

Fernandez, O., 241, 496

Fiehn, O., 1628

Filippone, M. P., 1430

Finley, S., 1350

FixL-fixK signal transduction cascade, in Rhizobium etli, FxkR and, 1506

Flagella, rice-Azoarcus sp. strain BH72 interactions and, 191

Flg22 peptide, activation of MPK11 in Arabidopsis thaliana by, 471

Floryszak-Wieczorek, J., 1469

Flp pili, Ralstonia solanacearum virulence on potato and, 546

Fluhr, R., 85

Fobert, P. R., 1459

Fongen, M., 1450

Fontaine, F., 496

Fossdal, C. G., 1450

Fragaria $\times$ ananassa (strawberry), Colletotrichum fragariae on, ellagitannin accumulation and plant defense response, 1430

Francis, I., 637

Franco, F. P., 613

Frank, W., 363

Frendo, P., 1478

Frey, P., 279

Friedrich, F., 28

Friesen, T. L., 515

Fujii, T., 1015

Fukumoto, T., 1419

Furutani, A., 505

Furuya, N., 18

Fusarium spp.

F. graminearum

on maize, development, deoxynivalenol production, and phenolic acid accumulation in, 1605

OS-2 as key regulator in life cycle of, 1142, cover photo: September

peroxisome and virulence and survival of, 1617

Tri12 protein, virulence to wheat and trichothecene accumulation and, 1408 on wheat, salicylic acid and basal resistance to, 431
F. oxysporum

f. sp. lycopersici, secreted-in-xylem (SIX) proteins and virulence in Arabidopsis, 180

visualizing and quantifying in plant host, 1531

$F$. virguliforme, on soybean, expression of single-chain variable-fragment antibody against toxin peptide of, resistance and, 817, cover photo: June

FxkR, fixL-fixK signal transduction cascade in Rhizobium etli and, 1506

Gac/Rsm regulatory pathway, of Pseudomonas fluorescens, ppGpp and biocontrol activity, 1440

Gallie, D. R., 1628

Galvani, C. D., 1132

Gao, F., 964

Gao, R., 1574

Gao, S., 440

García, J. A., 151

García-Agustín, P., 709

García-Calderón, M., 211

García-Marcos, A., 709

Gardiner, D. M., 180

Gassmann, W., 862

GCR1, promotion of Arabidopsis primary root elongation by AHL and, 677

Gene-for-gene hypothesis, effector triggered immunity signaling and, 862

Georgellis, D., 1506

Geurts, R., 954

Ggt1. See G-Glutamyl transpeptidase

Giacomelli, L., 1118

Giesbert, S., 481

Gijzen, M., 896

Gilmer, D., 1058

Gil-Serrano, A., 825

Girard, L., 1506

Giraud, E., 851

Glawischnig, E., 1186

Glazebrook, J., 1628, 471

Glick, B. R., 668

GlnD proteins, nitrogen metabolism in Sinorhizobium meliloti-alfalfa symbiosis and, 355

Glomus sp., double-stranded RNA in, mycorrhizal symbiosis and, 1005

GLT gene, of Colletotrichum gloeosporioides, pathogenicity and, 1251

Gluconic acid, GOX2 gene of Penicillium expansum and, 779

Glucosinolate, germination stimulants of Phelipanche ramosa in Brassica napus rhizosphere derived from, 993

Glutamine synthetase

inhibition by phosphinothricin and transcriptome reprogramming in root nodules of Medicago truncatula, 976

Lotus japonicus mutants deficient in, symbiotic association with Mesorhizobium loti bacteria and, 211

$\gamma$-Glutamyl transpeptidase (Ggt1), Sclerotinia sclerotiorum sclerotia and compound appresoria development and, 412

Glutathione

Rhizobium etli glutamine utilization and symbiotic effectiveness and, 331

Sclerotinia sclerotiorum sclerotia and compound appresoria development and, 412

Glycine max (soybean)

Bradyrhizobium spp. and

B. aponicum, ECF16 sigma factor EcfS and, 119, cover photo: January

MLST method for genotype identification and establishing nodule occupancy, 321

Fusarium virguliforme on, expression of single-chain variable-fragment antibody 
against toxin peptide of, resistance and,

817 , cover photo: June

Soybean mosaic virus in, multiple defense genes in Rsv1-mediated extreme resistance, 1307

Xanthomonas axonopodis pv. glycines on,

$\mathrm{XagR}$ and virulence, 1104

Glycosyl hydrolases (GH), Magnaporthe oryzae virulence and, 1135

Gmitter, F. G. Jr., 1396

Gobena, D., 1350

Göhre, V., 1083

Goldman, G. H., 613

Gombert, J., 341

Gómez-Hernández, N., 1506

Gomi, K., 1419

Gonzalez-Ibeas, D., 107

Gonzalez-Lamothe, R., 1584

Goverse, A., 1045

GOX2 gene, of Penicillium expansum, gluconic acid production and acidification during fruit colonization and, 779

GPA1, promotion of Arabidopsis primary root elongation by AHL and, 677

Grape. See Vitis vinifera

Grau, B. L., 393

Gravot, A., 1478

Greer, K., 271

Grellet, C., 1430

Griffitts, J. S., 1026

Grigoriev, I. V., 443, 1350

Gronover, C. S., 200

Grosic, S., 1307

Guan, D., 393

Guerinot, M. L., 119

Guerri, J., 1326

Gully, D., 851

Guo, H.-S., 964

Guo, Y., 165

Gypsophila paniculata, HSVGT of, regulation by HsvG of Pantoea agglomerans pv. gypsophila, 231

Haas, B. J., 1350

Haas, D., 1440

Hacquard, S., 279

Haeuser-Hahn, I., 481

Halkier, B. A., 1186

Hamelin, R. C., 279

Han, C. S., 1350

Hardham, A. R., 379

Hardoim, P., 28

Harman, G. E., 1264

Hauberg-Lotte, L., 28

HCPro, of Plum pox virus, replacement of with

$\mathrm{P} 1 \mathrm{~b}$ silencing suppressor from Cucumber vein yellowing virus, 151, cover photo: February

HCRSV. See Hibiscus chlorotic ringspot virus

He, C., 1361

Heller, J., 802

Henrique-Silva, F., 613

Herglotz, J., 191

Herranz, M. C., 1093

Hessian fly. See Mayetiola destructor

Heterobasidion parviporum, on Norway spruce, host defense and oxalic acid production, 1450

Hibiscus chlorotic ringspot virus (HCRSV), coat protein of, upregulation of sulfur metabolism genes for enhanced pathogen defense and, 1574

Hietala, A. M., 1450

High-throughput screening, of Xanthomonas citri subsp. citri on citrus, genes involved in virulence, 69

Hikichi, Y., 1219

Hildbrand, M., 1198

Hill, J. H., 1307

Hleibieh, K., 1058
Hoch, H. C., 1132

Holsters, M., 637

Holub, E. B., 877

Hong, J. C., 48

Hop effectors, sense-post-transcriptional gene silencing and, $\mathbf{4 4 0}$

Hopkins, J., 1478

Hordeum vulgare (barley)

Blumeria graminis f. sp. hordei on, genes regulating Mla-triggered immunity and basal defense, 1492, cover photo: November

induction of broad-spectrum resistance in by Pseudomonas pathosystem, similarity to Arabidopsis systemic acquired resistance, 658

Rhynchosporium commune on, necrosisinducing proteins of as effectors in quantitative disease resistance, 1314

Horizontal gene transfer

from Agrobacterium spp. to Linaria in nature, 1542

rhizobial HR plasmids and, 1026, cover photo: August

Hormone signaling, Potato spindle tuber viroid in tomato and, 582

Horowitz, S. B., 779

Horwitz, B. A., 931

Host resistance

of Arabidopsis thaliana against Cucumber mosaic virus yellow strain, $R C Y 1$ and, 1171 of barley

against Blumeria graminis f. sp. hordei, WRKY genes and, 1492, cover photo: November

against Rhynchosporium commune, necrosisinducing proteins and, 1314

against Colletotrichum fragariae on strawberry, ellagitannin and, 1430

of dandelion against Pseudomonas syringae pv. tomato, polyphenol oxidase isoform and, 200

against Fusarium graminearum on maize, chlorogenic acid and, 1605

against Fusarium virguliforme on soybean, expression of single-chain variablefragment antibody against toxin peptide and, 817, cover photo: June

of maize against Fusarium graminearum, chlorogenic acid and, 1605 against Phytophthora infestans on potato, 910

against Pseudomonas syringae pv. tomato on dandelion, polyphenol oxidase isoform and, 200

against Rhynchosporium commune on barley, necrosis-inducing proteins and, 1314 against Rice stripe virus, systems approach for studying components of, 534

of soybean

against Fusarium virguliforme, expression of single-chain variable-fragment antibody against toxin peptide and, 817, cover photo: June

against Soybean mosaic virus, multiple defense genes in Rsv1-mediated extreme resistance, 1307

of strawberry against Colletotrichum fragariae, ellagitannin and, 1430

TGA transcription factors of Arabidopsis thaliana and, 1459

HR plasmids, impaired symbiotic nitrogen fixation, enhanced host invasion and, 1026, cover photo: August

H.Shimura,, 1275

Hsieh, M.-H., 738

HsvG, of Pantoea agglomerans pv. gypsophila, regulation of Gypsophila paniculata HSVGT and, 231
HSVGT, of Gypsophila paniculata, regulation by HsvG of Pantoea agglomerans pv. gypsophila, 231

Huang, L., 755

Huang, Q., 1639

Huitema, E., 1350

Hulvey, J., 1350

Hung, T.-H., 648

Hurek, T., 28

Hurlbert, J. C., 307

Hurley, U., 379

Hurtado-Gonzales, O. P., 1350

Hwang, D., 534

Hwang, I., 534

Hyaloperonospora arabidopsidis, Nep1-like protein of, 697

Hypersensitive response (HR)

of pepper against Xanthomonas spp., AvrBs proteins and, 307

Pseudomonas syringae pv. tomato on tomato and, 294

IAOx (indole-3-acetaldoxime)- derived compounds, Piriformospora indica and root colonization, 1186

Ichimura, K., 1419

Ikeda, K., 1552

Ikeda, Y., 1005

Imkampe, J., 1230

Immunodominant membrane protein (IDP), of Candidatus Phytoplasma mali, binding to plant actin, 889

Innate immunity, chitin-induced, ethyleneresponsive element-binding factor 5 (ERF5) and, 48

Ionescu, M., 453, 1104

Ipomoea batatas (sweet potato), Streptomyces ipomoeae on, thaxtomin $\mathrm{C}$ as pathogenicity determinant and, 393

Irieda, H., 625

Ishiga, T., 294

Ishiga, Y., 294

Ishihama, N., 1015

Ishikawa, N., 18

Itoh, K., 1135

Izumi, Y., 1419

Jackson, O., 1338

Jacobsen, E., 910

Jacquens, L., 496

Jahn, M. M., 1562

Janus, L., 1469

Jarausch, B., 889

Jarausch, W., 889

Jasmonic acid, Colletotrichum coccodes on tomato and, ammonium secretion and modulation of, 85

Jawdy, S. S., 765

Jaziri, M. El, 637

Jenkins, J., 1350

Jia, P.-S., 964

Jia, Z., 677

Jin, H., 440

Jindrichová, B., 1238

Johnson, J. M., 1186

Joly, D. L., 279

Jones, A. M. E., 1083

Jones, D. A., 379

Jones, J. B., 307

Jones, J. D. G., 941

Kahn, M. L., 355

Kahnt, J., 1230

Kai, K., 684

Kalantidis, K., 440

Kaldenhoff, R., 259

Kalkus, J., 637

Kamoun, S., 910, 1350 
Kanayama, Y., 1171

Kang, B.-C., 1562

Kang, J., 896

Kang, Z., 755

$\mathrm{K}$-antigen polysaccharides (KPS), Rpk3 genes of Sinorhizobium fredii and, 825

Karademiris, K., 440

Karlovsky, P., 569

Karve, A. A., 765

Katagiri, F., 471

Kazan, K., 180

Khajuria, C., 920

Khalaf, A., 1396

Kiba, A., 1219

Killiny, N., 453

Kim, H. J., 48

Kim, J.- ., 1617

Kim, J., 1562

Kim, K., 534

Kim, S.-M., 534

Kingsmore, S. F., 1350

Kirsten, S., 1314

Kistler, H. C., 1408

Kitahara, R., 1005

Knight, J. R., 1350

Knogge, W., 1314

Knox, J. P., 1338

Kobayashi, K., 1219

Kodama, M., 1015

Kohler, A., 279

Koizumi, E., 18

Kong, G., 896

Korban, S. S., 6

Kour, A., 271

Krause, A., 28, 191

Krczal, G., 889

Küfner, I., 697

Kuo, A., 1350

Kupas, V., 481

Kusano, T., 1171

Kuwata, S., 18

Kvaalen, H., 1450

Kwak, D.-Y., 534

$L$ genes, of Capsicum spp., evolution of, 1219

Laccase, appresorial melanization and conidial pigmentation in Colletotrichum orbiculare and, 1552

Lahrmann, U., 727

Laiosa, M. D., 37

Lamb, C., 658

Lamour, K. H., 1350

Laperche, A., 1478

LAR. See Localized acquired resistance

Lariagon, C., 1478

Larkov, O., 931

Lasseur, B., 341

Lawrence, C. B., 443

Lawrence, G. J., 379

Le Bizec, B., 993

Leduc, N., 402

Lee, B.-C., 534

Lee, H., 431

Lee, H.-R., 910

Lee, J., 1617, 471

Lee, S., 534

Lee, Y.-W ., 1617

Legué, V., 279

Lehtonen, M. T., 363

Leitner, A., 1314

Lemon, rough. See Citrus jambhiri

Lenzi, L., 1118

Leptosphaeria maculans, AvrLm1 from, salicylic acid and ethylene signaling in Brassica napus and, 1238

Lethal systemic necrosis, in tomato, viral satellite RNA infection and, 1034

Li, D., 1639
Li, J.-L., 165

Li, M., 412

Li, T.-K., 648

Li, X., 1459

Li, Y., 1132

Li, Z.-G., 1396

Liang, X., 412

Lichter, A., 779

Lin, F. K., 1574

Lin, N.-C., 648

Lin, S. Y., 1552

Lin, S.-S., 648

Lin, Y.-C., 279

Linaria vulgaris, horizontal gene transfer from Agrobacterium spp. to in nature, 1542

Lindow, S. E., 453, 1104

Lindquist, E. A., 1350

Lindsay, D. P., 1026

Lipopolysaccharide (LPS), Rpk3 genes of Sinorhizobium fredii and, 825

Litt, A., 603

Liu, F., 677

Liu, J., 1639, 1459

Liu, P., 1574

Liu, X., 920

Lobaria pulmonaria, Dictyochloropsis reticulata and, congruent genetic structure in 220

Localized acquired resistance (LAR), Oidium neolycopersici on tomato and, 375

Long, S. R., 1026

López-Solanilla, E., 523

Loria, R., 393

Loss of heterogeneity, in Phytophthora capsici, rapid adaptation and, 1338

Lotus japonicus

symbiotic association with Mesorhizobium loti bacteria, behavior of mutants deficient in glutamine synthetase, 211

tissue-specific transcriptome analysis in nodules of, 869

LRR1 (leucine-rich repeat 1), RCY-1 mediated resistance to of Arabidopsis thaliana against Cucumber mosaic virus yellow strain and, 1171

Lu, H.-C., 738

Lu, T.-Y., 765

Lugan, R., 1478

Lukasik-Shreepaathy, E., 1045

Luna, A. P., 1294

Luteolinidin, from Sorghum bicolor, host specificity of Sporisorium reilianum and, 1230

Lutova, L. A., 1542

Ma, J.-y., 1034

Macquet, A., 341

Magnaporthe spp.

M. grisea, MGOS database and, 271

M. oryzae

cellulases and virulence of, 1135

nutrient acquisition and utilization during infection by, 1286

Maize. See Zea mays

Makandar, R., 431

Malbeck, J., 1073

Malvar, R. A., 61

Mamaní, A., 1430

Manacorda, C. A., 1370

Mann, H., 603

Manners, J. M., 180

Manulis-Sasson, S., 231

Manzanares-Dauleux, M. J., 1478

Manzano, A., 709

MAP Kinase, programmed cell death in Nicotiana umbratica and, AAL toxin, ethylene signaling and, 1015

Marchegay, G., 1605
Margaret, I., 825

Mariani, P., 1387

Márquez, A. J., 211

Martin, F., 279

Martin, G. B., 1523

Martin, M. Z., 765

Mase, K., 1015

Massaroli, M., 802

Mastouri, F., 1264

Masunaka, A., 1419

Masuta, C., 18, 1005, 1171, 1275

Mateos, P. F., 1594

Matern, A., 1314

Matos, J. L., 613

Matsuda, Y., 372

Matsuura, H., 18

Matveeva, T. V., 1542

Mayetiola destructor (Hessian fly), on wheat, rapid membrane lipid mobilization in leaf sheaths and, 920

McConkey, B. J., 668

McDonald, B. A., 515

McGrann, G. R. D., 658

Medeiros, A. H., 613

Medicago spp.

M. sativa (alfalfa), nitrogen metabolism in symbiosis with Sinorhizobium meliloti, 355

M. truncatula, inhibition glutamine synthetase by phosphinothricin and transcriptome reprogramming in root nodules of, 976

MEK2, programmed cell death in Nicotiana umbratica and, AAL toxin, ethylene signaling and, 1015

Melampsora larici-populina, on poplars, candidate effectors in, 279 , cover photo: March

Melanin, Colletotrichum orbiculare LAC2 gene and, 1552

Melon. See Cucumis melo

Melton, S. J., 765

Membrane attachment, $\mathrm{N}$-terminal domains in plant disease resistance proteins and, 379

Menéndez, E., 1594

Meng, X., 1251

Meng, Y., 1492

Menke, J., 1408

MEPB gene, of Colletotrichum gloeosporioides, pathogenicity and, 1251

Mesorhizobium spp.

M. ciceri, $c l p B$ gene and nodulation of chickpea, 1594

M. loti, Lotus japonicus mutants deficient in glutamine synthetase and, 211

Metabotyping, for investigation of rapeseed genetic diversity in metabolic response to clubroot infection, 1478

Metagenomic analysis, of endophyte community colonizing rice roots, 28

Meyer, M., 1198

Meyer, R. S., 603

MGOS (Magnaporthe grisea-Orzya sativa) database, overview of, 271

Microbe-associated molecular patterns (MAMP), XopR protein of Xanthomonas oryzae pv. oryzae and suppression of, 505

MicroRNAs (miRNAs), Aphis gossypii on melon and, expression profile during aphid herbivory in resistant and susceptible interaction, 839

Milczarek, G., 1469

Mildew locus a (Mla)-mediated immunity, to Blumeria graminis f. sp. hordei, WRKY genes and, 1492, cover photo: November

Miller, N. A., 1350

Min, K., 1617

Minami, E., 505

Minsavage, G., 307 
Mith, O., 941

Mitogen-activated protein kinases

MPK11, activation of in Arabidopsis thaliana by flg22, 471

in Nicotiana benthamiana, $\mathrm{Nep} 1_{\mathrm{Mo}}$-triggered plant responses and, 1639

Sak1 of Botrytis cinerea, regulatory functions of, 802

Mitter, B., 28

Miyamoto, Y., 1419

Miyara, I., 1251

Mizumoto, H., 1219

Mizuno, T., 1015

MLST. See Multilocus sequence typing

Moerschbacher, B. M., 200

Moffett, P., 1523

Mohammadi, M., 463

Monteiro, F., 557

Montiel, G., 993

Moore, G. A., 1396

Moreau, M., 421

Moreno, J., 825

Moreno, P., 1326

Mori, H., 1015

Morilla, G., 1294

Morrell-Falvey, J. L., 765

Morte, A., 259

Mortreau, E., 402

Moscatiello, R., 1387

Moser, C., 1118

Moskovitch, O., 779

Moss. See Physcomitrella patens

Motyka, V., 1073

Mou, Z., 1209

Moura, D. S., 613

Movement protein (MP), of Tobacco mosaic virus, plant basal defense and biotic stress responses in Nicotiana tabacum and, 1361

Mowery, P., 1132

MP. See Movement protein

MPK. See Mitogen-activated protein kinase

Mudge, J., 1350

Mueller, L. A., 1523

Mukhtar, M. S., 877

Multilocus sequence typing (MLST), for identification of genotypes within

Bradyrhizobium spp. and establishing nodule occupancy of soybean, 321

Munteanu, B., 889

Murdoch, P. S., 825

Murphy, J. F., 1562

Mycoviruses, in arbuscular mycorrhizal fungi, symbiosis and, 1005

Mysore, K. S., 294

$N^{\prime}$ gene, of Nicotiana sylvestris, evolution of, 1219

eNAD $(\mathrm{P})$, systemic acquired resistance in Arabidopsis thaliana and, 1209

$\mathrm{NADPH}$-dependent thioredoxin reductase $\mathrm{C}$ (NTRC), P. syringae pv. tomato on tomato and, 294

Nagy, N. E., 1450

Nakayashiki, H., 1135

Nakazono, M., 869

Nalam, V. J., 431

Nanni, V., 1118

Natsuaki, T., 18

Navarro, L., 1326

Navarro-Quezada, A., 1314

Navarro-Ródenas, A., 259

Navazio, L., 1387

Necrosis- and ethylene-inducing-like proteins. See NLP

Necrosis-inducing proteins. See NIP

Nep1-like proteins. See NLP

Nester, E. W., 1542

Newman, K. L., 453
Nguyen, Q. B., 1135

Nguyen, T. V., 1142

Nguyen, X. C., 48

Nicotiana spp.

N. benthamiana,

Colletotrichum orbiculare on, induction and suppression of cell death by secreted proteins of, 625

draft genome sequence of, 1523

mitogen-activated protein kinases in, $\mathrm{Nep}_{\mathrm{Mo}^{-}}$ triggered plant responses and, 1639

$N$. sylvestris, $N^{\prime}$ gene of, evolution of, 1219

$N$. umbratica, programmed cell death in, AAL toxin, ethylene signaling pathway, MAPK cascades and, 1015

NIP (necrosis-inducing proteins), of

Rhynchosporium commune on, quantitative disease resistance and, 1314

NIS1 protein, Colletotrichum orbiculare on Nicotiana benthamiana, induction of cell death and, 625

Nishiguchi, M., 1219

Nishimura, M. T., 877

Nishizawa, Y., 505

Nissan, G., 231

Nitric oxide, exposure of potato to priming agent and, 1459

Nitrogen metabolism genes expressed during pathogenicity of the alkalinizing Colletotrichum gloeosporioides and their differential expression in acidifying pathogens, 1251

Sinorhizobium meliloti-alfalfa symbiosis and, 355

NLP (Nep1-like protein)

of Hyaloperonospora arabidopsidis, 697

Nicotiana benthamiana MAPK cascade, WRKY

transcription factors and, 1639, cover photo:

December

in Phytophthora sojae, groups lacking necrosis-inducing activity and, 896

from Verticillium dahliae, molecular characterization and functional analysis, 964

Noguchi, M., 18

Nongbri, P. L., 1186

Nonomura, T., 372

Nonphotochemical quenching, PAMP-triggered immunity and, 1083

Norman, D., 307

Norway spruce. See Picea abies

Nostoc spp., arabinogalactan proteins in, 1338

Nováková, M., 1238

NPR1 (nonexpressor of pathogenesis-related genes 1), Arabidopsis Clade I TGA transcription factors and plant defenses, 1459

$\mathrm{N}$-terminal domains, membrane attachment, disease resistance and, 379

$N T R C$. See NADPH-dependent thioredoxin reductase $\mathrm{C}(N T R C)$

Nürnberger, T., 697

Ochiai, H., 505

Oelmüller, R., 1186

Ogata, Y., 684

Ogawa, T., 684

Ohm, R. A., 443

Ohshima, K., 18

Ohta, D., 684

Ohtani, K., 1419

Oidium neolycopersici, on tomato, localized acquired resistance and, 375

Oilseed rape. See Brassica napus

El Oirdi, M., 1584

Okuda, S., 1552

Okuno, T., 1552, 625

Ol-4 resistance gene, Oidium neolycopersici on tomato and, 375
Oligogalacturonides, as novel signaling molecules in Rhizobium-legume communications, 1387

Oliveira, S., 1594

Oliver, R. P., 515

Oome, S., 697

Op den Camp, H. J. M., 954

Op den Camp, R. H. M., 954

OPDA (12-oxo-phytodienoic acid), Hessian fly on wheat and, 920

Orbach, M. J., 271

Orchid, high-throughput VIGS vector for screening transcription factors involved in plant defense responses in, 738

Oryza sativa (rice) interactions with Azoarcus sp. strain BH72, flagella and endophytic competence, 191 metagenomic analysis of endophyte colony characterizing, 28

MGOS database and, 271

OS-2, as regulator of Fusarium graminearum life cycle, 1142, cover photo: September

Owens, R. A., 582

Oxalic acid, defense of Norway spruce against Heterobasidion parviporum and, 1450

Oxiles, L., 443

P126 protein, of Tobacco mosaic virus, RNAi silencing and, 648, cover photo: May

P1b silencing suppressor, of Cucumber vein yellowing virus, functional replacement of Plum pox virus HCPro and, 151, cover photo: February

P25 pathogenicity factor, of Beet necrotic yellow vein virus, sugar beet $26 \mathrm{~S}$ proteasome and hypersensitive resistance response, 1058

Pacheco, R., 709

Pallas, V., 1093

PAMP. See Pathogen-associated molecular patterns

Panopoulos, N. J., 440

Pantoea spp.

P. agglomerans pv. gypsophila, type III effector HsvG of, expression of host HSVGT and, 231

$P$. stewartii subsp. stewartii, on corn, endoglucanase and full virulence, 463

Paquis, S., 241

Parasponia andersonii, Rhizobium tropici WUR1 and nodulation, 954, cover photo: July

Pasmanik-Chor, M., 231

Pathogen-associated molecular pattern (PAMP)triggered immunity, molecular cross-talk with photosynthesis, 1083

Pathogen-associated molecular patterns (PAMP), activation of MPK11 in Arabidopsis thaliana by flg22 peptide, 471

Patrel, D., 851

Patriarca, E. J., 331

Patrit, O., 421

Pavlova, O. A., 1542

Pawlak-Sprada, S., 1469

PCD. See Programmed cell death

PdeK/PdeR, of Xanthomonas oryzae pv. oryzae, c-di-GMP turnover and virulence, 1361

Pecher, P., 471

Peever, T. L., 1419

Pelletier, D. A., 765

Peña, L., 1326

Peng, Q., 37

Penicillium expansum, GOX2 gene of, gluconic acid production and acidification during fruit colonization and, 779

Penselin, D., 1314

Pepper. See Capsicum spp.

Pereira, P. A., 976

Perez, K., 1562

Péron, T., 402 
Peroxidases, oxidative burst upon treatment of moss plants with fungal elicitor and, 363

Peroxin (PEX) proteins, Fusarium graminearum virulence and survival and, 1617

Pertry, I., 637

Petre, B., 279

Pettis, G. S., 393

PFiD188, as linear virulence plasmid of

Rhodococcus fascians, 637

PGPR. See Plant-growth-promoting rhizobacterium

Phalaenopsis aphrodite, high-throughput VIGS vector for screening transcription factors involved in plant defense responses in, 738

Phelipanche ramosa (pomel)

germination stimulants of in Brassica napus rhizosphere derived from glucosinolate pathway, 993

PrSus 1 gene and, 402

Phenolic compounds

Cochliobolus heterostrophus on maize and, 931

Colletotrichum fragariae on strawberry and, 1430

Fusarium graminearum on maize and, 1605

PhoP/PhoQ system, Dickeya dadantii virulence and, 523

Phosphinothricin, inhibition glutamine synthetase by and transcriptome reprogramming in root nodules of Medicago truncatula, 976

Photosynthesis, molecular cross-talk with PAMP-triggered immunity, 1083

Physcomitrella patens (moss), oxidative burst upon treatment with fungal elicitor, 363

Phytoalexins, from Sorghum bicolor, host specificity of Sporisorium reilianum and, 1230

Phytophthora

$P$. capsici, heterozygosity loss as mechanism for rapid adaptation in, 1350

$P$. infestans, on potato cultivar Sarpo Mira, perception of five distinct RXLR effectors and, 910

$P$. sojae, NLP toxin family in, groups lacking necrosis-inducing activity and, 896

Picea abies (Norway spruce), Heterobasidion parviporum on, host defense and oxalic acid production, 1450

Picot, A., 1605

Pieterse, C. M. J., 139

PII proteins, nitrogen metabolism in

Sinorhizobium meliloti-alfalfa symbiosis and, 355

Pil-Chp operon, Xylella fastidiosa twitching, motility, and virulence and, 1132

Pinson-Gadais, L., 1605

Piriformospora indica

IAOx-derived compounds and restriction of root colonization, 1186

molecular and genomic analysis of lifestyle, 727

Plant growth-promoting rhizobacteria (PGPR)

Burkholderia phytofirmans

grape and, modulation of carbohydrate metabolism and cold acclimation, 496 grape tolerance to low nonfreezing temperatures and, 241 effects of bacterial ACC deaminase on gene expression in Brassica napus and, 668

Plasmodiophora brassicae, on rapeseed, metabotyping for investigating metabolic response to, 1478

Platt, D., 1350

Plum pox virus (PPV), HCPro of, replacement of with $\mathrm{P} 1 \mathrm{~b}$ silencing suppressor from Cucumber vein yellowing virus, 151, cover photo: February
Polar surface attachment, by Rhizobium leguminosarum bv. viciae, arabinogalactanlike glycoprotein and, 250

Polle, A., 569

Polone, E., 954

Polyphenol oxidase (PPO), dandelion resistance against Pseudomonas syringae pv. tomato and, 200

Pomel. See Phelipanche ramosa

Pons, S., 1605

Popa, C., 941

Populus spp., Melampsora larici-populina on, candidate effectors in, 279, cover photo: March

Potato

nitric oxide-mediated stress imprint in, exposure to priming agent and, 1459

Phytophthora infestans on, perception of five distinct RXLR effectors and, 910

Ralstonia solanacearum on, type IVb pili and virulence, 546

Potato spindle tuber viroid (PSTVd), in tomato, hormone signaling and, 582

Potato virus $X$ (PVX)

in tomato, identification of mutants affected in $R x$-mediated resistance, 341

transcriptomic and hormonal responses to compatible and incompatible plant-virus interactions leading to cell death and, 709

Potnis, N., 307

Pouponneau, K., 993

Pouvreau, J.-B., 402, 993

PP2Ac, Botrytis cinerea virulence and, 481

ppGpp, biological control activity of

Pseudomonas fluorescens and, 1440

PPO. See Polyphenol oxidase

PPV. See Plum pox virus

Pradhan, B. B., 789

Pradhan, Binod B., 1157

Prathuangwong, S., 1104

Price, J. C., 1026

Pritchard, L., 523

Programmed cell death (PCD)

in Nicotiana umbratica, AAL toxin, ethylene signaling pathway, MAPK cascades and, 1015

Puccinia striiformis f. sp. tritici on wheat,

TaMCA4 gene and, 755

transcriptomic and hormonal responses to compatible and incompatible plant-virus interactions leading to, 709

Prüfer, D., 200

Prusky, D., 85, 779, 1251

Pseudomonas spp.

P. fluorescens

ppGpp controlled by Gac/Rsm regulatory pathway and biocontrol activity, 1440

strain-dependent and strain-independent host plant responses to, 765

$P$. syringae, on bean, molecular basis of host specialization in pathovars of, 877

P. syringae pv. syringae, regulation of biosynthesis of syringolin A of, 1198

$P$. syringae pv. tomato

on tomato, effect of NTRC and chloroplastgenerated reactive oxygen species on disease development, 294

tomato and, polyphenol oxidase isoform and host resistance, 200

PTSVd. See Potato spindle tuber viroid

Puccinia striiformis f. sp. tritici, on wheat, TaMCA4 gene and programmed cell death, 755

PVX. See Potato virus X

Pyrenophora tritici-repentis, ToxA activity and, 515

Qi, M., 6
Quirin, E. A., 603

Quorum sensing

diffusible signal factor-mediated, Xanthomonas citri subsp. citri gene expression and, 165

GCR1 and GPA1 and Arabidopsis primary root elongation, 677

Qutob, D., 896

$R$ genes

Phytophthora infestans on potato and, 910

of Solanum spp., evolutionary meta-analysis of, cross-species comparisons and, 603

Raffaele, S., 1350

Rafiqi, M., 379

Rahalkar, M., 28

Rai, R., 789

Ralstonia solanacearum

awr gene family and novel type III effectors, 941

on potato, type IVb pili and virulence, 546

tools for promoter probing, mutant complementation, and pathogenicity studies in, 557

Ramel, C., 1198

Ranjan, M., 789, 1157

Rape. See Brassica napus

Rcs phosphorelay system, in Erwinia amylovora, genome-wide identification of genes regulated by, 6

$R C Y 1$, resistance to Cucumber mosaic virus yellow strain and, 1171

Reactive oxygen species (ROS)

Fusarium graminearum life cycle and, 1142 oxidative burst upon treatment of moss plants with fungal elicitor and, 363

Pseudomonas syringae pv. tomato on tomato and, 294

Trichoderma harzianum on tomato and defense against, 1264

Reese, J. C., 920

Regulation of pathogenicity genes. See Rpf genes

Reinhold-Hurek, B., 28, 191

Renou, J.-P., 421

Reski, R., 363

Reutimann, L., 119

Reyes-González, A., 1506

Rhizobacteria. See also Specific species

Burkholderia phytofirmans

grape and, modulation of carbohydrate metabolism and cold acclimation, 496 grape tolerance to low nonfreezing temperatures and, 241

effects of bacterial ACC deaminase on gene expression in Brassica napus and, 668

HR plasmids, impaired nitrogen fixation and enhanced host invasion and, 1026, cover photo: August

oligogalacturonides as signaling molecules and, 1387

Rpk3 genes of Sinorhizobium fredii and Kantigen polysaccharide biosynthesis, lipopolysaccharide structure, and legume infection, 825

Rhizobium spp.

R. etli

FxkR and fixL-fixK signal transduction cascade, 1506

requirement of glutathione for glutamine utilization and symbiotic effectiveness, 331

R. leguminosarum bv. viciae, arabinogalactan-like glycoprotein from, novel type of polar surface attachment and, 250

R. tropici WUR1, Parasponia andersonii and nodulation, 954, cover photo: July 
Rhizosphere

modulation of host immunity by beneficial microbes in, 139

oligogalacturonides as signaling molecules in, 1387

Rhodococcus fascians, pFiD188 as linear virulence plasmid of, 637

Rhynchosporium commune, necrosis-inducing proteins of as effectors in quantitative disease resistance, 1314

Riccio, A., 331

Rice. See Oryza sativa

Rice, B. J., 1350

Rice, J., 355

Rice stripe virus (RSV), systems approach for studying resistance factors to, 534

Richard-Forget, F., 1605

Richter, C., 200

Richter, H., 1045

Rietman, H., 910

Rio-Alvarez, I., 523

Ripoll, D. R., 1562

Rivera, P., 1506

RNA silencing

Brome mosaic virus and, 97

p126 protein of Tobacco mosaic virus and suppression of, 648, cover photo: May

plant viral diseases and, 1275

suppressors from viruses causing tomato yellow leaf curl disease, functional analysis of, 1294, cover photo: October

RNA silencing suppressors (RSS)

from Cucumber vein yellowing virus, in Plum pox virus, 151, cover photo: February

from viruses causing tomato yellow leaf curl disease, functional analysis of, 1294, cover photo: October

Robatzek, S., 1083

Robledo, M., 1594

Rodier-Goud, M., 851

Rodrigues, R., 307

Rodriguez, M. C., 1370

Rodríguez, V. M., 61

Rodríguez-Carvajal, M. A., 825

Rodríguez-Herva, J. J., 523

Rodríguez-Navarro, D. N., 825

Rodríguez-Palenzuela, P., 523

Roelofsen, W., 954

Rogers, E. E., 747

Rollins, J. A., 412

Roossinck, M. J., 1034

Roper, M. C., 463

Rosli, H. G., 1523

Roucolle, J., 1605

Rough lemon. See Citrus jambhiri

Rouzé, P., 279

RpfB, Xylella fastidiosa cell-to-cell signal synthesis, virulence, and vector transmission of, 453

Rpk3 genes, of Sinorhizobium fredii, K-antigen polysaccharide biosynthesis, lipopolysaccharide structure, and legume infection, 825

RSS. See RNA silencing suppressors

RSV. See Rice stripe virus

$R s v 1$, extreme resistance to Soybean mosaic virus and, 1307

Ruhnke, N., 802

Ruíz-Lozano, J. M., 259

Ruiz-Ruiz, S., 1326

Ruiz-Sainz, J. E., 825

RXLR effectors, Phytophthora infestans on potato and, 910

$R x$-mediated resistance, of tomato against Potato virus $X, 341$

Rybak, K., 515
Saccharum spp. (sugarcane), Sugarwin gene from, as insect-induced genes with antipathogenic activity, 613

Sachs, S., 191

Saga, H., 684

Saitoh, H., 1219

Sak1, of Botrytis cinerea, regulatory functions of, 802

Sakurai, N., 684, 869

Salamov, A., 1350

Salicylic acid

basal resistance to Fusarium graminearum on wheat and, 431

Colletotrichum coccodes on tomato and, ammonium secretion and modulation of, 85

promotion of disease development in tomato and, 1584

signaling in Brassica napus, AvrLm1 gene from Leptosphaeria maculans and, 1238

Salicylic acid-induced protein kinase (SIPK), programmed cell death in Nicotiana umbratica and, AAL toxin, ethylene signaling and, 1015

Sander, N., 697

Sanjuán, J., 825

Sano, T., 582

Santiago, R., 61

Santos-Silva, L. K., 613

Sarkar, A., 28

Sarris, P. F., 440

Šašek, V., 1238

Satellite RNA, lethal systemic necrosis in tomato and, 1034

Sattar, Interaction S., 839

Savidor, A., 1350

Schädeli, D., 1198

Schadt, C. W., 765

Schäfer, W., 1142

Scheel, D., 471

Scheidegger, C., 220

Schirawski, J., 1230

Schmutz, J., 1350

Schreier, P. H., 481

Schumacher, J., 481

Sclerotinia sclerotiorum, $\gamma$-glutamyl transpeptidase and sclerotia and compound appresoria development, 412

Seabra, A. R., 976

Secreted-in-xylem (SIX) proteins, Fusarium oxysporum virulence in Arabidopsis and, 180

Segmüller, N., 481

Sehabiague, P., 1605

Seiffert, U., 1314

Seifi, A., 372

Sekine, K.-T., 1219

Sesamia nonagrioides (corn borer), on maize, transcriptome and biochemical analysis of inducible defense mechanisms against, 61

Sessa, G., 231

Sessitsch, A., 28

Shah, J., 431

Shalaby, S., 931

Shao, J. Y., 582

Sharma, R., 1350

Shearer, H. L., 1459

Shen, T.-L., 648

Sherameti, I., 1186

Sherman, A., 779, 1251

Shibata, D., 684, 869

Shimura, H., 18, 1005

Shnaiderman, C., 1251

Shoji, H., 1171

Silencing. See RNA silencing

Silencing suppressors

from Cucumber vein yellowing virus, in Plum pox virus, 151, cover photo: February from viruses causing tomato yellow leaf curl disease, functional analysis of, 1294, cover photo: October

Silva-Filho, M. C., 613

Silverstein, K. A. T., 1118

Simier, P., 402, 993

Simón-Mateo, C., 637

Singh, S., 569

Sinorhizobium spp.

$S$. fredii, rpk3 genes of, $\mathrm{K}$-antigen polysaccharide biosynthesis, lipopolysaccharide structure, and legume infection, 825

HR plasmids, impaired nitrogen fixation and enhanced host invasion and, 1026, cover photo: August

S. meliloti, nitrogen metabolism in symbiosis with alfalfa, 355

SIPK. See Salicylic acid-induced protein kinase

SIX proteins. See Secreted-in-xylem proteins

Sklenár, J., 1083

Slootweg, E., 1045

Small secreted proteins (SSP), in Melampsora larici-populina on poplars, 279

Smith, J. K., 307

Smith, N. A., 1275

SNF. See Symbiotic nitrogen fixation (SNF)

Soderlund, C., 271

Sohn, K. H., 941

Solanum lycopersicum (tomato)

Alternaria solani on, salicylic acid and disease development, 1584

Colletotrichum coccodes on, ammonium secretion during infection and salicylic and jasmonic acid pathways, 85

genetic loci controlling lethal cell death in, viral satellite RNA infection and, 1034

Oidium neolycopersici on, localized acquired resistance and, 375

$P$. syringae pv. tomato on, effect of NTRC and chloroplast-generated reactive oxygen species on disease development, 294

Potato spindle tuber viroid in, hormone signaling and, 582

Potato virus $X$ in, identification of mutants affected in $R x$-mediated resistance, 341

Trichoderma harzianum on, antioxidant defense of seedlings and resistance to water deficit, 1264

use of salicylic acid by pathogens for disease development in, 1584

Solanum spp., evolutionary meta-analysis of Rgenes, cross-species comparisons and, 603

Solé, M., 557, 941

Solheim, H., 1450

Son, G. H., 48

Son, H., 1617

Song, Q., 321

Song, S., 677

Song, W., 1639

Song, Y., 839

Sorghum bicolor, luteolinidin production by, host specificity of Sporisorium reilianum and, 1230

Soto, M. J., 825

Soybean. See Glycine max

Soybean mosaic virus (SMV), in soybean, multiple defense genes in Rsv1-mediated extreme resistance, 1307

Sporisorium reilianum, host specificity of, luteolinidin production by Sorghum bicolor and, 1230

Spruce, Norway. See Picea abies

SPT3, Botrytis cinerea virulence and, 481

Squartini, A., 954, 1387

Srivastava, A., 443

SSP. See Small secreted proteins 
Stacey, G., 48

Stagonospora nodorum, ToxA activity and, 515

Stall, R. E., 307

Stam, R., 1350

Stanley, W. A., 515

Stearns, J. C., 668

Steeber, D. A., 37

Stockwell, S. B., 119

Storey, D., 1350

Strawberry. See Fragaria $\times$ ananassa

Streptomyces ipomoeae, on sweet potato, thaxtomin $\mathrm{C}$ as pathogenicity determinant and, 393

Stukenbrock, E. H., 515

Sturbois, B., 341

Sucrose synthase, Phelipanche ramosa development and, 402

Sueda, K., 18

Sugar beet. See Beta vulgaris

Sugarcane. See Saccharum spp.

Sugarwin genes, from sugarcane, as insectinduced genes with antipathogenic activity, 613

Sugimoto, F., 625

Sugiyama, A., 869

Suicide vectors, for promoter probing, mutant complementation, and pathogenicity studies in Ralstonia solanacearum, 557

Sulfur metabolism, coat protein of Hibiscus chlorotic ringspot virus and enhanced pathogen defense, 1574

Sun, L., 1361

Sundin, G. W., 6

Sunkar, R., 839

Sus1 gene, Phelipanche ramosa development and, 402

Suzuki, H., 684, 869

Suzuki, M., 1171

Sweet potato. See Ipomoea batatas

Symbiosis

arabinogalactan proteins, Nostoc spp. and, 1338

Bradyrhizobium spp. and soybean, MLST method for genotype identification and establishing nodule occupancy, 321

clpB gene of Mesorhizobium ciceri and root nodulation of chickpea, 1594

of Dictyochloropsis reticulata and Lobaria pulmonaria, congruent genetic structure in, 220

double-stranded RNA in arbuscular mycorrhizal fungi and, 1005

IAOx-derived compounds and restriction of Piriformospora indica root colonization, 1186

of Lotus japonicus and Mesorhizobium loti, behavior of mutants deficient in glutamine synthetase, 211

Nod-independent Rhizobium-legume, Aeschynomene evenia as model plant for studying, 851

Parasponia andersonii-rhizobium, 954, cover photo: July

rhizobial HR plasmids, impaired nitrogen fixation and enhanced host invasion and, 1026, cover photo: August

Sinorhizobium meliloti-alfalfa, nitrogen metabolism in, 355

Symbiotic nitrogen fixation (SNF), tissuespecific transcriptome analysis in nodules of Lotus japonicus and, 869

Syringolin A, of Pseudomonas syringae pv. syringae, regulation of, 1198

Systemic acquired resistance (SAR), in Arabidopsis thaliana, expression of human NAD(P)-metabolizing ectoenzyme CD38 and, 1209

Sztuba-Solinska, J., 97
Tada, Y., 1419

Takahashi, H., 869, 1171

Takanashi, K., 869

Takano, Y., 1552, 625

Takemoto, D., 379

Takeshita, M., 18, 1171

Takeuchi, K., 1440

Takeuchi, S., 1219

Takken, F. L. W., 1045

TaMCA4 gene, Puccinia striiformis $\mathrm{f}$. sp. tritici on wheat, programmed cell death and, 755

Tan, K.-C., 515

Tang, C., 755

Tang, J., 896

Tang, Y., 1034

Tanguay, P., 279

Taraxacum officinale (dandelion), Pseudomonas syringae pv. tomato and, polyphenol oxidase isoform and host resistance, 200

Taté, R., 331

Taylor, C. M., 393

Taylor, M., 1034

Taylor, O., 1338

$T c A Q P 1$, of desert truffle, as membrane pore for water and carbon dioxide transport, 259

Tech, K. B., 582

Teng, W., 1639

Tenllado, F., 709

Teper, D., 231

Terfezia claveryi (desert truffle), aquaporin $T c A Q P 1$ of, as membrane pore for water and carbon dioxide transport, 259

TGA transcription factors, of Arabidopsis thaliana, plant defense regulation and, 1459

Thatcher, L. F., 180

Thaxtomin C, as pathogenicity determinant of Streptomyces ipomoeae on sweet potato, 393

Theocharis, A., 241, 496

Theron, J., 546

Thiel, H., 1058

Thines, M., 1350

Thoiron, S., 402

Thompson, G. A., 839

Thon, M., 1251

Tian, F., 1361

Timpner, C., 569

Tisserant, E., 279

Tobacco etch virus (TEV), in Capsicum spp., determination of infectivity by three amino acids in $\mathrm{VPg}, 1562$

Tobacco mosaic virus (TMV)

coat protein and movement proteins of, plant basal defense and biotic stress responses in Nicotiana tabacum and, 1361

p126 protein and suppression of local and systemic RNAi silencing, 648, cover photo: May

Tomato. See Solanum lycopersicum

Tomato yellow leaf curl disease (TYLCD), functional analysis of gene-silencing suppressors from viruses causing, 1294, cover photo: October

Tomita, R., 1219

Tosa, Y., 1135

Toth, I., 6, 523

Town, C. D., 1118

ToxA genes, from Stagonospora nodorum and Pyrenophora tritici-repentis, 515

Toyoda, H., 372

Traini, A., 603

Transcriptome analysis

of Sesamia nonagrioides on corn, 61

tissue-specific in nodules of Lotus japonicus, 869

of tolerant rough lemon and susceptible sweet orange in response to Candidatus Liberibacter asiaticus infection, 1396
Tri12 protein, of Fusarium graminearum, virulence to wheat and trichothecene accumulation and, 1408

Trichoderma harzianum, on tomato, antioxidant defense of seedlings and resistance to water deficit, 1264

Trichothecenes, Tri12 protein of Fusarium graminearum and, 1408

Trick, H. N., 431

Triticum aestivum (wheat)

Fusarium graminearum on, salicylic acid and basal resistance to, 431

Hessian fly on, rapid membrane lipid mobilization in leaf sheaths and, 920

Puccinia striiformis f. sp. tritici on, TaMCA4 gene and programmed cell death, 755

Truffle, desert. See Terfezia claveryi

Tschaplinski, T. J., 765

TSPO proteins, oxidative burst upon treatment of moss plants with fungal elicitor and, 363

Tsuchiya, K., 18

Tsuda, K., 471

Tsuge, S., 505

Tudzynski, P., 481, 802

TuMV. See Turnip mosaic virus

Turnip mosaic virus (TuMV), in Nicotiana benthamiana, synergism with Cucumber mosaic virus, 18

Tuskan, G. A., 765

$26 \mathrm{~S}$ proteasome, of sugar beet, $\mathrm{P} 25$ pathogenicity factor of Beet necrotic yellow vein virus and, 1058

TYLCD. See Tomato yellow leaf curl disease

Type III secretion systems (T3SS)

in Dickeya dadantii 3937, bistable gene expression of, 37

Hop effectors and sense-post-transcriptional gene silencing, 440

of Pantoea agglomerans pv. gypsophila, regulation of Gypsophila paniculata HSVGT and, 231

Pseudomonas syringae bean pathovars and 877

of Ralstonia solanacearum, Awr gene family and, 941

Type IV pili (T4P), Ralstonia solanacearum virulence on potato and, 546

Uhse, S., 1230

Uppalapati, S. R., 294

Utermark, J., 1230

Valent, B., 271

Valentová, O., 1238

Valerius, O., 569

Valkonen, J. P. T., 363

Valli, A., 151

Valls, M., 557, 941

van Berkum, P., 321

Van de Peer, Y., 279

Van den Ackerveken, G., 697

van der Waals, J. E., 546

van Dijk, I., 557

van Elsas, J. D., 28

van Overbeek, L., 28

van Schalkwyk, A., 546

Vandeputte, O. M., 637

Vargas, W. A., 1251

Varrelmann, M., 1058

Vedel, R., 421

Velázquez, K., 1326

Vereecke, D., 637

Véronési, C., 402

Verticillium spp.

$V$. dahliae, necrosis- and ethylene-inducing, protein-encoding gene family from, 964 
V. longisporum, on oilseed rape, expression of catalase peroxidase and late stage of disease, 569

Vf19 gene, Alternaria brassicicola virulence and, 443, cover photo: April

Vicente, J., 877

Vinardell, J. M., 825

Viral genome-linked protein $(\mathrm{VPg})$, of Tobacco etch virus, infectivity in Capsicum spp. and, 1562

Virus-induced gene silencing (VIGS) in orchid, high throughput system for screening transcription factors in, 738 viral vectors based on Citrus leaf blotch virus and, 1326

Visser, R. G. F., 910

Vitis vinifera (grape)

Burkholderia phytofirmans and modulation of carbohydrate metabolism and cold acclimation, 496

tolerance to low nonfreezing temperatures and, 241

Defensin-like (DEFL) genes in, 1104

Vleeshouwers, V. G. A. A., 910

Voinnet, O., 1294

von Tiedemann, A., 569

Vossen, J. H., 910

VPg. See Viral genome-linked protein

Vrebalov, J., 1523

Vu, B. V., 1135

Wagner, G., 1478

Wairuri, C. K., 546

Wan, J., 48

Wang, D., 6

Wang, H., 896, 920, 1034

Wang, H.-I., 738

Wang, L., 1459

Wang, L.-Y., 648

Wang, M., 1639

Wang, M.-B., 1275

Wang, N., 69, 165

Wang, X., 755

Wang, Y., 896

Wangdi, T., 294

Washington, E. J., 505

Watermelon mosaic virus (WMV), in melon, recessive resistance associated with induction of defense response genes in, 107

Waters, O.D. C., 515

Weber, A. P. M., 1083

Wei, G., 755

Weihmann, F., 1073

Weilharter, A., 28

Welin, B., 1430

Welti, R., 920

Wenzel, C., 1314
Werth, S., 220

Weston, D. J., 765

Wheat. See Triticum aestivum

Whitham, S. A., 1307

Whitworth, R. J., 920

Williams, A., 250

Wilson, R. A., 1286

Win, J., 1350

WIPK. See Wound-induced protein kinase

Wirsel, S. G. R., 1073

Wise, R. P., 1492

WMV. See Watermelon mosaic virus

Wong, S.-M., 1574

Woody, O. Z., 668

Wound-induced protein kinase (WIPK), programmed cell death in Nicotiana umbratica and, AAL toxin, ethylene signaling and, 1015

Woyke, T., 28

WRKY genes

in Nicotiana benthamiana, $\mathrm{Nep}_{\mathrm{Mo}_{\mathrm{o}}}$-triggered plant responses and, 1639

resistance of barley against Blumeria graminis f. sp. hordei and, 1492, cover photo: November

Wu, M., 1361

XadM, of Xanthomonas oryzae pv. oryzae, attachment, biofilm formation, and virulence of, 1157

XagR, virulence of Xanthomonas axonopodis pv. glycines on soybean and, 1104

Xanthomonas spp.

$X$. axonopodis pv. glycines, on soybean, $\mathrm{XagR}$ and virulence, 1104

$X$. citri subsp. citri

on citrus, high-throughput screening and analysis of genes involved in virulence, 69 diffusible signal factor-mediated quorum sensing and gene expression in, 165

$X$. oryzae pv. oryzae

atypical regulation of virulence-associated functions by diffusible signal factor in, 789

PdeK/PdeR and c-di-GMP turnover and virulence of, 1361

XadM and attachment, biofilm formation, and virulence, 1157

XopR protein of, suppression of MAMP in Arabidopsis thaliana and, 505

on pepper, AvrBs proteins and hypersensitive response, 307

Xie, F., 250

XopR protein, of Xanthomonas oryzae pv. oryzae, suppression of MAMP in Arabidopsis thaliana and, 505

$\mathrm{Xu}, \mathrm{P} ., 1034$
Xylella fastidiosa

Arabidopsis thaliana as model host for, 747

Pil-Chp operon and twitching, motility, and virulence in, 1132

$r p f B$ and cell-to-cell signal synthesis, virulence, and vector transmission of, 453

Yamada, K., 1440

Yamaoka, N., 1219

Yan, Q., 69

Yang, C.-H., 37, 1361

Yang, F., 1361

Yang, X., 765

Yazaki, K., 869

Yeam, I., 1562

Yeh, H.-H., 738

Yeheskel, A., 231

Yoneyama, K., 993

Yoshino, K., 625

Yoshioka, H., 625, 1015

Yu, Q., 1396

Yu, X., 896

Yurgel, S. N., 355

Zaini, P. A., 1132

Zamioudis, C., 139

Zamorano-Sánchez, D., 1506

Zea mays (corn, maize)

Cochliobolus heterostrophus on, use of aromatic compounds as signals and metabolites, 931

Colletotrichum graminicola on, remodeling cytokinin metabolism at infection sites, 1073

Fusarium graminearum on, development, deoxynivalenol production, and phenolic acid accumulation in, 1605

Pantoea stewartii subsp. stewartii on, endoglucanase and full virulence, 463

Sesamia nonagrioides on, transcriptome and biochemical analysis of inducible defense mechanisms against, 61

Zeng, Q., 37

Zhang, C., 1307

Zhang, H., 1639

Zhang, X., 1209

Zhang, Y., 165, 1459

Zhang, Z., 1639

Zhao, Q., 677

Zhao, Y., 6

Zheng, X., 1639

Zhou, B.-J., 964

Zhu, L., 920

Zhuang, J., 1118

Zuccaro, A., 727

Zuther, K., 1230 